\title{
Efektivitas Inkubator Portable Sebagai Alat Inovasi Penunjang Laboratorium Mikrobiologi
}

\author{
Sudirman Halla ${ }^{1}$, Rohmi $^{2}{ }^{2}$ Agrijanti $^{3}$ \\ ${ }^{1}$ Jurusan Analis Kesehatan, Poltekkes Kemenkes Mataram, Indonesia
}

\section{Article Info \\ Article history: \\ Received Des $22^{\text {th }}, 2018$ \\ Revised Jan $21^{\text {st }}, 2019$ \\ Accepted Feb 23 ${ }^{\text {st }}, 2019$}

Keyword:

Bacteria

Incubator

Portable

\begin{abstract}
Background: a conventional incubator is a tool that is designed to meet the needs of the process of incubation dilaboratorium microbiology using a hefty tool components are expensive and require a voltage high at a time when the word fair dilaboratorium. While the portable incubator designed using materials that can be easily and relatively cheaply, at the time of its use dilaboratorium any need voltage a bit, on a portable incubator tool components in complete with temperature sensor and temperature regulator as in conventional incubators. Goal: Designing, designing and munguji portable incubators as a tool supporting the microbiology laboratory innovations in complete regulator temperature and LCD. Method: This research is a type of study "experimental" which aims to create a simple tool that can grow bacteria through the incubation process. Results and Conclusions: bacterial growth average in planting in incubation in media last NAP in portable incubator and incubator conventional as control obtainable right results and conclusions baha incubator portable feasible in use as incubator microbiology laboratories supporting alternatives in particular field of incubation.
\end{abstract}

\begin{abstract}
ABSTRAK
Latar Belakang : inkubator konvensional merupakan alat yang didesain untuk memenuhi kebutuhan pada proses inkubasi dilaboratorium mikrobiologi yang mengunakan komponen alat yang lumayan mahal dan membutuhkan tegangan listrik lumayan tinggi pada saat pengunaannya dilaboratorium. Sedangkan inkubator portable di rancang menggunakan bahan yang mudah di dapat dan relatif murah, pada saat penggunaannya dilaboratorium pun membutuhkan tegangan listrik yang sedikit, pada komponen alat inkubator portable di lengkapi dengan sensor suhu dan pengatur suhu seperti pada inkubator konvensional. Tujuan : Mendesain, merancang dan munguji inkubator portable sebagai alat inovasi penunjang laboratorium mikrobiologi yang di lengkapi pengatur suhu dan LCD. Metode : penelitian ini merupakan jenis penelian "experimental"yang bertujuan untuk membuat alat sederhana yang bisa untuk menumbuhkan bakteri yang melalui proses inkubasi. Hasil dan Kesimpulan: rata rata pertumbuhan bakteri yang di tanam pada media NAP lalu di inkubasi pada inkubator portable dan inkubator konvensional sebagai kontrol didapat kan hasil dan kesimpulan baha inkubator portable layak di gunakan sebagi inkubator alternatif penunjang laboratorium mikrobiologi khususnya bidang inkubasi.
\end{abstract}

Kata Kunci : Bakteri, Inkubator, Portable 


\section{Pendahuluan}

Seorang ilmuwan mikroorganisme, Koch dan rekan-rekannya telah mengembangkan beberapa prosedur laboratorium yang mempunyai dampak luar biasa terhadap perkembangan mikrobiologi, khusunya bakteri. Hal ini mencakup prosedur untuk mewarnai bakteri agar mudah memeriksanya (mudah diamati) dan teknik untuk membiakan (menumbuhkan) mikroba di laboratorium.(Sugiyono 2016) Bakteri merupakan suatu organisme yang jumlahnya paling banyak di bumi. Bakteri umumnya bersel satu, tidak memiliki membran inti sel, berukuran sangat kecil, serta memiliki peran besar di bumi. Beberapa kelompok bakteri dikenal sebagai agen penyebab infeksi dan penyakit, sedangkan kelompok lainnya dapat memberikan manfaat dalam bidang pangan, pengobatan, dan industry. Sebelum bakteri diolah menjadi sesuatu yang bermanfaat, bakteri harus dikembangbiakkan terlebih dahulu menggunakan alat inkubator.

Pada umumnya inkubator bakteri perannya sangat penting karena berfungsi sebagai alat instrument paling penting dalam proses menumbuhkan mikroorganisme seperti fungi, bakteri dan sel mikroba lainnya. Alat ini sering di jumpai dai laboratorium mikrobiologi dibandingkan dengan laboratorium kimia dan laboratorium lainnya.

Untuk mengembangbiakan bakteri membutuhkan suhu yang cocok dengan kondisi biologis dan fisik bakteri dengan waktu tertentu.bakteri tersebut dikembangbiakkan menggunakan sebuah alat penginkubasi inkubator bakteri, Pada inkubator juga dibutuhkan pengatur suhu dan waktu sebagai proses inkubasi bakteri, karena setiap spesies bakteri memerlukan suhu dan waktu perkembangbiakan yang berbeda. Contohnya bakteri yang membutuhkan waktu 24 jam untuk berkembangbiak, apabila diberi waktu lebih dari itu maka bakteri tersebut akan mati.(Pratiwi 2016)

Inkubator yang sering digunakan di rumah sakit atau laboratorium menggunakan inkubator konvensional yang sangat mahal. Sistematik yang rumit berkapasitas besar dan menggunakan daya listrik yang tinggi, Sehingga menyebabkan seorang teknisi sulit dalam melakukan pengoprasian maupun perbaikan alat, ketika terjadi kerusakan. Karena faktor tersebut inkubator konvensional tidak bisa di gunakan di tempat-tempat tertentu seperti puskesmas terpencil yang jauh di pelosok dan yang tidak memiliki sarana aliran listrik. Berdasarkan hal tersebut peneliti ingin mencari inovasi untuk melakukan penelitian yaitu membuat alat inkubator laboratorium portable dengan prinsip kerja yang sama dengan inkubator laboratorium konvensional tetapi inkubator tersebut bersifat praktis, murah, hemat energi dan dengan biaya produksi yang rendah.

\section{MetodePenelitian}

Penelitian ini menggunakan rancangan penelitian praeksperimental karena penelitian ini di lakukan dengan cara memanipulasi atau mengontrol suatu kondisi alamiah dengan cara membuat kondisi buatan (artificial condition). Dengan demikian penelitian yang di lakukan dengan memanipulasi objek penelitian, serta adanya kontrol yang di sengaja terhadap objek penelitian.

Pengambilan sampel dalam penelitian ini dengan teknik probability sampling yaitu simple random sampling. Menurut Sugiyono (12), Probability sampling adalah teknik pengambilan sampel yang memberikan peluang yang sama bagi setiap unsur (anggota) populasi untuk dipilih menjadi anggota sampel. Simple random sampling dinyatakan simple (sederhana) karena pengambilan sampel dilakukan secara acak tanpa 
memperhatikan strata yang ada dalam populasi itu

\section{Hasil Penelitian dan Pembahasan}

Tabel 4.1. Pertumbuhan inbakteri pada Inkubator Konvensional dan Inkubator Portable.

\begin{tabular}{|c|c|c|c|c|c|}
\hline No & Jenis Inkubator & \multicolumn{3}{|c|}{ Pertumbuhan Bakteri Pada Media } & Keterangan \\
\hline & $\begin{array}{l}\text { Konvensional } \\
\text { kontrol }\end{array}$ & + & + & + & $+=$ tumbuh \\
\hline & $\begin{array}{l}\text { Portable } \\
\text { Objek penelitan }\end{array}$ & + & + & + & $\begin{aligned}-= & \text { tidak } \\
& \text { tumbuh }\end{aligned}$ \\
\hline
\end{tabular}

Pada tabel 4.1. Menunjukan hasil pengamatan pertumbuhan bakteri memperlihatkan bahwa inkubator portable dapat di gunakan sebagai alat inovasi penunjang laboratorium mikrobiologi.

Penelitian telah di lakukan di Laboratorium Mikrobiologi Jurusan analis Kesehatan pennelitian ini bersifat eksperimental, dengan tujuan untuk membuat alat alternatif yang menunjang pemeriksaan mikrobiologi khususnya di bidang inkubasi.

Desain alat agar lebih mudan membuat bagian-bagian alat di gunakan kumputerisasi karena kita lihat pada proses desain alat yang telah di lakuakan oleh peneliti yang lain untuk membuat alat masih menggunakan tulisan tangan sehingga hasil yang di peroleh kurang akurat dan jika di lakukan desain menggunakan komputerisasi hasil yang di peroleh sangat akurat dari segi ukuran dan tampilan yang di peroleh bisa kita lihat pada gambar pedesainan alat pada gambar 4.1desain alat inkubator.

Perancangan alat inkubator atau proses pemasangan komponen alat di lakukan sesuai proses desain sehingga komponen alat tidak kurang satupun shingga pada saat proses pengujian alat berfungsi dengan baik dapat kita lihat pada gambar 4.3 rancangan alat inkubator portable.

Setelah di lakukan desain dan perancangan alat tentunya alat akan di uji dengan cara mengerami media yang telah di tanami dengan bakteri yang spesifik tumbuh pada suhu kisaran $37^{\circ}$ dan yang dan membutuh kan oksigen (aerob), adapun salah satu jenis bakteri yang di inokulasi pada media NAP tersebut adalah bakteri Ecoli, setelah bakteri tersebut di inokulasi pada media lalu di lakukan proses inkubasi pada dua inkubator yaitu Inkubator Portable dan Inkubator Konvensional sebagai kontrol,dan didapat kan hasil seperti yang di tampilkan pada gambar 4.7 a, b pada dan gambar 4.8 a dan b pengecatan koloni hasil inkubasi pada Inkubator Portable Dan Inkubator Konvensional sebagai kontrol bagian hasil pengujian alat.

Adapun kelebihan dari Inkubator bakteri, menggunakan chip mikrokontroler sebagai pengendali suhu, dengan harga yang terjangkau. Mikrokontroler yang digunakan mempunyai tingkat kesalahan sangat kecil sehingga efisien jika digunakan. Menggunakan 2 buah lampu pijar sebagai heater(pemanas) dan daya listrik yang digunakan rendah

\footnotetext{
${ }^{\square}$ Korespodensi: Sudirman Halla, Sudirmanhalla@ gmail.com, +62823399651041, Jurnal AnalisMedika Bio Sains
} 


\section{Kesimpulan}

Alat inkubator portable dapat digunakan di laboratoirum untuk melakukan proses inkubasi pada bakteri, ditandai dengan terjadinya pertumbuhan koloni bakteri setelah di inkubasi menggunakan incubator portable dan setelah dilakukan pengecatan gram.

\section{Daftar Pustaka}

Dewa Made Subrata., 2013. Rancang Bangun Incubator dengan Suhu dan Kelembaban Udara Terkendali untuk Penetasan Telur Ulat Sutera. , 1(1), pp.85-91.Departemen Teknik Mesin dan Biosistem, FATETA-IPB, PO Box 220,Perpustakaan Kampus IPB Darmaga - Bogor.

Gede Panca S, Perancangan dan Pembuatan Pengaturan Suhu InkubatorBayi Berbasisn Mikrokontroler AT89S51, ,http://teundiksha.files.wordpress.com/2010/05/perancangan-dan pembuatansuhu-inkubator-bayi-at-mega-89s51.pdf (tanggal akses 10 Agustus 2011

Latif, A. \& Iswanto, 2016. Low-cost portable heart rate monitoringbased on photoplethysmography and decision tree. In Anvances OfscienceandTechnologi For Society: Proceedings of the 1stInternational Conference on Science and Technology 2015 (ICST-2015). p.090004. Available at:http://scitation.aip.org/content/aip/proceeding/aipcp/10.1063/1.4958522.

Pelczar,M.J and other. 2008,Dasar-dasar Mikrobiologi.Jilid pertama.UniversitasIndonesia(UIPress).Jakarta

Pelczar,M.J and other. 2008,Dasar-dasar Mikrobiologi.Jilid kedua.UniversitasIndonesia(UI-Press).Jakarta

Purbonoto,G, Chomsyarini.2011. Peracangan dan Pembuatan Inkubator BakteriUntuk Mengetahui Jumlah Bakteri dalam Proses Pembuatan KertasMengunakan PLC.ITS Library. Surabaya

Pratiwi, R., Perbedaan daya hambat terhadap Streptococcus mutans dari beberapa pasta gigi yang mengandung herbal ( The difference of inhibition zones toward Streptococcus mutans among several herbal toothpaste )., pp.64-67. perpustakaanUniversitas HasanuddinMakassar.

Rossy Tiara Vadiska1, I Dewa Gede Hari Wisana2, M.Ridha Mak'ruf3 et al., 2015. Seminar Tugas Akhir Juni 2015 Seminar Tugas Akhir Juni 20152 . Teori Penunjang Tujuan. , (2010), pp.112.perpustakaan politeknik kesehatan surabaya

Setiawan, TY.2011.Perancangan Inkubator Berbasis Mikrokontroler AVRATMega8535. Politeknik Muhammadiyah Yogyakarta. Yogyakarta. 